\title{
Tarihî Türkçe Metinlerde Farsça İzafet ve Atıf Tamlamalarında Görülen Dudak Uyumu ve Çeviri Yazı Üzerine Birkaç Öneri
}

\section{A Few Suggestions on Labial Harmony and Translation in Persian Noun and Reference Phrases in Historical Turkish Texts}

\author{
Mehmet Mustafa KARACA $^{1}$ (D)
}

'Sorumlu yazar/Corresponding author: Mehmet Mustafa Karaca (Dr. Öğr. Üyesi), Aydın Adnan Menderes Üniversitesi, Fen Edebiyat Fakültesi, Türk Dili ve Edebiyatı Bölümü, Aydın, Türkiye E-posta:mmkaraca@adu.edu.tr ORCID: 0000-0001-9763-3151

Başvuru/Submitted: 17.08.2021 Revizyon Talebi/Revision Requested: 10.09.2021

Son Revizyon/Last Revision Received: 29.09.2021

Kabul/Accepted: 30.09 .2021

Online Yayın/Published Online: 04.11.2021

Atıf/Citation: Karaca, Mehmet Mustafa. “Tarihî Türkçe Metinlerde Farsça İzafet ve Atıf Tamlamalarında Görülen Dudak Uyumu ve Çeviri Yazı Üzerine Birkaç Öneri." Türkiyat Mecmuası-Journal of Turkology 31, Özel Sayı (2021): 115-130.

https://doi.org/10.26650/iuturkiyat.984104 öz

Bir medeniyet ve kültür dili olarak Türkçe dünyanın en eski yazılı belgelerine sahip dillerden biridir. Türkler tarih boyunca çok geniş coğrafyalarda onlarca devlet kurmuş ve pek çok toplumla temas hâlinde bulunmuşlardır. Bu durum temas edilen toplumlar ile hemen her alanda bazı alışverişleri de beraberinde getirmiştir. Bu alışverişlerin en önemlilerinden biri de şüphesiz dile dair alışverişlerdir. Bu alışverişler kimi zaman kelime ve gramer yapısı şeklindeyken kimi zaman da alfabe şeklinde gerçekleşmiştir. Türk dilinin yazılı metinlerden takip edebildiğimiz en eski dönemi VII-VIII. yüzyıllara dayanmaktadır. VII-VIII. yüzyıllardan günümüze kadar pek çok alfabe değişikliği yaşandığı da malumdur. Özellikle XX. yüzyıl başlarına kadar gerek Köktürk alfabesi gibi millî alfabeler gerekse diğer toplumlardan alınan veya Türkçeye uyarlanan alfabeler incelendiğinde bu alfabelerin Türk dilinin ihtiyaçlarını karşılamakta ve inceliklerini yansıtmakta yetersiz kaldıkları görülmektedir. Bugün özellikle ses bilgisi çalışmalarında alfabelerin yetersizliklerinden kaynaklı olarak bazı seslerin tarihî gelişimini ve değişimini tespit etmek kimi zaman imkânsız hâle gelmektedir. Bunun yanı sıra alıntılanan kelimelerin ve gramer yapılarının ne şekilde imla edileceği de ayrı bir zorluk olarak karşımıza çıkmaktadır. Türkoloji çalışmalarında önemli ölçüde bir yazım birliği sağlanmış olsa da bazı hususlar henüz çözüme kavuşmamış veya gözden kaçmıştır. Bu yazıda Farsça izafet ve atıf tamlamalarında meydana gelen dudak uyumu incelenerek dudak uyumuna bağlı olarak oluşan imlanın çeviri yazıda nasıl gösterilmesi gerektiğiyle ilgili önerilere yer verilecektir.

Anahtar kelimeler: Türk dili, Fonetik, Çeviri Yazı, Farsça İzafet Tamlaması, Atıf Tamlaması

\section{ABSTRACT}

As a language of civilization and culture, Turkish is one of the languages used in some of the oldest written documents in the world. Turks have established states in vast geographies throughout history and have been in contact with many societies. This contact has resulted in some exchanges in almost every field. One of the most important of these exchanges is undoubtedly the interaction of languages. In addition to the vocabulary and grammatical structures, there are multiple occasions where foreign alphabets are borrowed. The Turkish language has also undergone many alphabet changes since the 7th-8th centuries, which 
we can follow through written texts. When both the Köktürk alphabet and the alphabets taken from other societies are examined, it is seen that these alphabets are insufficient to meet the needs of the Turkish language and do not reflect its subtleties, especially until the beginning of the 20th century. Today, it is sometimes impossible to determine the historical development and change of some sounds due to the inadequacies of alphabets, especially in phonetics studies. In addition to this, how to transcript the loanwords and grammatical structures is another challenge. Although transcription unity has been achieved to a great extent in Turcology studies, some issues have not been resolved yet or were overlooked. In this article, the labial harmony occurring in Persian noun and reference phrases will be examined and suggestions will be given about how the orthography, which is formed due to labial harmony, should be shown in the translated text.

Keywords: Turkish Language, Phonetics, Translation, Noun Phrase, Reference Phrase

\section{EXTENDED ABSTRACT}

As a language of civilization and culture, Turkish is one of the languages used in some of the oldest written documents in the world.Turks have established states in vast geographies throughout history and have been in contact with many societies. This contact has resulted in some exchanges in almost every field. One of the most important of these exchanges is undoubtedly the exchange of language. In addition to the vocabulary and grammatical structures, it is seen that foreign alphabets are also borrowed in several occasions. The Turkish language has undergone many alphabet changes from the $7^{\text {th }}-8^{\text {th }}$ centuries, which we can follow through written texts. When both the Köktürk alphabet and the alphabets taken from other societies are examined, it is seen that these alphabets are insufficient to meet the needs of the Turkish language and do not reflect its subtleties, especially until the beginning of the $20^{\text {th }}$ century. Today, it is sometimes impossible to determine the historical development and change of some sounds due to the inadequacies of alphabets, especially in phonetics studies. In addition to this, how to transcript the loanwords and grammatical structures is another challenge. Although transcription unity has been achieved to a great extent in Turcology studies, some issues have not been resolved yet or were overlooked. The point we would like to focus on is the labial harmony in Persian noun and reference phrases as well as how to show the sound changes that occur due to this harmony in the translated text. There is no clear consensus concerning the labialization of the unrounded

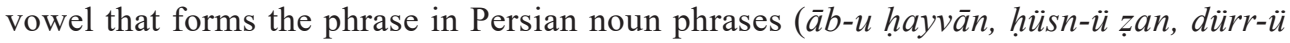
yetim etc.) and how to spell the utterance and spelling formed by the delabialization of the connecting preposition in Persian reference phrases (baş $\iota$ cān, șag $l$ șol, hakk $\iota$ băṭıl etc.) in the translation studies. Some researchers try to correct these sound events by attributing them to the ignorance of the authors and copyists, while researchers reflect these issues in their studies, albeit partially. In the studies we have made, it is understood that labial harmony in Persian noun and reference clauses started to be seen at the latest from the $15^{\text {th }}$ century and intensified in the $17^{\text {th }}$ and $18^{\text {th }}$ centuries, when the labial harmony was seen intensely in Turkish. In fact, in our opinion, this situation has affected the general orthography in some dialects and has become common orthography. We think that sounds that should not be rounded or unrounded, such as karż-u hasen, Cibrill-ü eminn, selātinn-u cihān, lutf $\mathrm{l}$ kahr, 
rūz $\iota$ şeb, Mecnūn ı Leyla etc, and so on, become rounded and unrounded by the effect of general orthography and by analogy. This situation, which has hundreds of examples from the 14 manuscripts that we have the opportunity to examine in our study, cannot be explained as the ignorance or negligence of the authors or copyists. On the contrary, it turns out that this situation is a normal phonetic event in the historical development process of the Turkish language. This is because it is very difficult to say that the same mistake is repeated in dozens of works and hundreds of examples written by different authors or copyists in different centuries in different geographies. Moreover, in the samples we have identified, the existence of sounds that affect the sound change phonetically, that is, have a rounding or unrounding effect, is also seen.

We have identified many examples from the 14 different manuscripts included in the study. However, we did not include all of the examples. We selected the examples repeated the most in the same work. Despite our desire to show the frequency of use by illustrating all examples found, we aimed to reveal the prevalence of labial harmony in Persian noun and reference phrases by taking a selection of different examples in order not to exceed the size of the article. However, when the same example occurs in different works, we try to include it in our study in order to show the frequency of use. As we have stated above, the issue we have mentioned has attracted the attention of some researchers. Since we did not have the opportunity to reach all of the manuscripts tacling this issue, we did not include examples that we could not witness in our work. Therefore, the examples given here present only part of the examples found in the literature. It is certain that the number and variety of examples related to the subject will increase depending on the number of works to be scanned. In this article, the labial harmony occurring in Persian noun and reference phrases will be examined and suggestions will be given about how the orthography, which is formed due to labial harmony, should be shown in the translated text. 


\section{Giriş}

Türk dilinin yazılı metinler üzerinden takip edilebilen en eski dönemi bilindiği üzere Eski Türkçe veya Köktürkçe olarak adlandırılan ve VII-VIII. yüzyıllara denk gelen dönemdir. Türk dili için kullanılan en eski alfabe ise yine Köktürk alfabesi, Türk Runik yazısı gibi adlarla adlandırılan alfabedir. Köktürk alfabesinden günümüze kadar farklı coğrafyalarda ve tarihî dönemlerde özellikle inanç değişiklikleri başta olmak üzere çeşitli sebeplerden dolayı pek çok alfabe kullanılmıştır. Kültürel alanda yaşanan hızlı değişmeler Türk yazı dilinin yazım kurallarının ve alfabe geleneğinin oluşmasını olumsuz yönde etkilemiştir. ${ }^{1}$ Kullanılan alfabelerden bazıları kısa süreli veya dar bir çevre içerisinde kullanılırken bazıları da daha geniş sahalarda ve daha büyük kültürler çevresinde kullanılmıştır. Burada, önemli yazılı metinlerin yazıya aktarıldığı alfabeler olan Köktürk, Uygur ve Arap alfabeleri hakkında kısaca şu bilgileri hatırlamak faydalı olacaktır.

Köktürk Alfabesi 38 harften meydana gelmektedir. Bu harflerden 4'ü ünlüleri, 34'ü ise ünsüzleri karşılamaktadır. Ünsüzler için kullanılan harflerden 20'sinin kalın ve ince olmak üzere iki şekli, 4'ü ünlü-ünsüz, ünsüz-ünlü olmak üzere iki sesi, 3'ü iki ünsüzden oluşan ünsüz çiftlerini, 7'si ise tek başına bir sesi karşılamaktadır. Burada özellikle ünlüler için kullanılan 4 harfin Türkçenin ünlülerini yansıtması bakımından yetersiz olduğu dikkat çekmektedir. Bu eksiklik ünsüzlerdeki kalınlık-incelik ve ünlü-ünsüz, ünsüz-ünlü çiftleriyle giderilmeye çalışılsa da bu düz ünlüler için mümkün olabilmektedir. Yuvarlak ünlülerde geniş ve dar ünlülerin birbirinden ayırt edilmesi mümkün olmamıştır. ${ }^{2}$

Eski Uygur alfabesi 18 harften oluşmakla birlikte bu alfabede bazı ünlü ve ünsüz sesler için aynı işaretlerin kullanıldığı görülmektedir. "Bu alfabede, ünlüleri işaretlemek için sadece üç işaret bulunmaktadır. $a$ ve $e ; l$ ve $i ; o, \ddot{o}, u$ ve $\ddot{u}$ ünlüleri aynı işaretle gösterilir. $o, \ddot{o}, u$ ve $\ddot{u}$ ünlülerini karşılayan harf, aynı zamanda diş-dudak $v$ sesini de karşılamaktadır. $l$ ve $i$ ünlülerinin temsilcisi ise, aslî olarak sedalı ön damak sonantı y'nin karşılığı olan harftir."’3

Arap alfabesi veya Arap temelli Türk alfabesi olarak da adlandırılan alfabe, Türk dilinin tarihî metinlerinin çoğunun yazıya aktarıldığı alfabedir. Bu alfabe yüzyılar boyunca çeşitli Türk devletleri ve toplulukları tarafından hem resmî yazışmalarda hem de edebî metinlerin meydana getirilmesinde yoğun bir şekilde kullanılmıştır. Bu alfabede /a/ ve /e/ sesleri için bir işaret, /o/, /ö/, /u/ ve /ü/ sesleri için bir işaret, /1/ ve /i/ sesleri için ise bir işaret kullanılmıştır. Dolayısıyla Arap alfabesinde /a/ ile /e/; /o/, /ö/, /u/, /ü/ ve /1/ ile /i/ seslerini birbirinden ayırt etmek için ayrıca bir işaretin olmayışı bu alfabenin de Türk dilinin seslerini tam olarak göstermek bakımından eksik kalmasına yol açmıştır.

1 Ali Akar, "Eski Oğuz Lehçesinde Alfabe Kaynaklı Fonolojik Bir Sorun: Ünsüzlerin Yazımı", Türkiyat Mecmuası 31/1 (2021), 4.

2 Ahmet Bican Ercilasun, Başlangıçtan Yirminci Yüzyıla Türk Dili Tarihi (Ankara: Akçağ Yayınları, 2008), 162 163.

3 Hatice Şirin User, Başlangıçtan Günümüze Türk Yazı Sistemleri (Ankara: Akçağ Yayınları, 2006), 60-61. 
Yukarıda Türk dili tarihinde hem tarihî önemleri hem de meydana getirildikleri eserlerin sayısı dikkate alınarak üç alfabenin temel özelliklerinden bahsedilmiştir. Bu alfabelerin sayısını çoğaltmak mümkündür. Ancak konunun özünden sapmamak gayesiyle kısaca değinilen bu alfabelerin ortak özellikleri görüldüğü gibi fonetik birer alfabe olmayışlarıdır. Alfabelerdeki bu özellikler Eski Türkçe döneminden XX. yüzyıl başlarına kadar yazılan eserlerin bugünkü alfabeye veya çeviri yazıya aktarılmasının yanında söz konusu metinlerin anlaşılmasında ve Türk dilinin fonetik değişimlerinin tespitinde bazı zorluklara sebebiyet vermektedir. Özellikle fonetik değişimlerin tespiti alfabelerden kaynaklı durumlardan dolayı bazen imkânsız hâle gelmektedir.

Söz konusu zorlukları ortadan kaldırmak maksadıyla alfabeler üzerinde bazı 1slah çalışmalarından da söz edilebilir. Özellikle Arap harfli tarihî metinlerde görülen üç noktalı kef, üç noktalı fe gibi işaretlerin yanında Arapçada olmayan /ç/, /p/,/y/ gibi Türkçe sesleri göstermek için geliştirilen veya Farsça üzerinden alfabeye dâhil edilen harfler kısmi birer 1slah faaliyeti olarak değerlendirilebilir. ${ }^{4} \mathrm{Bu}$ alfabenin özellikle İslam etkisiyle benimsenmesi, pek çok İslami eserin bu alfabeyle yazılması veya tercüme edilmesi, edebî metinlerdeki Farsça etkisi ile birleştirildiğinde Türk dilinin asırlar boyunca Arapça ve Farsçanın tesirinde kalmasına yol açmıştır. Bu tesir kelime alışverişinin ötesinde bazı gramer şekillerinin de Türkçeye girmesine yol açmış hatta bu durum bazı dönemlerde Türk dili için tehdit boyutuna ulaşmıştır. Her ne kadar yoğun bir Arap-Fars etkisi altında kalsa da Türk dili doğal yollarla bünyesine dâhil olan yapıların pek çoğunu Türkçeleştirmeyi ve varlığını devam ettirmeyi başarmıştır. Bununla birlikte Arapça ve Farsçadan alınan kelime veya yapılar bazen kaynak dildeki şekliyle bazen de Türkçenin ses ve şekil özelliklerine büründürülerek kullanılmaya devam etmiştir.

"Bir dile giren alıntı kelimelerde geldikleri dilden ayrılan fonetik özellikler bulunabilir. $\mathrm{Bu}$ durumda dil, almış olduğu kelimeleri kendi fonetik yapısına uydurma veya yaklaştırma çabası içine girer. Bu nedenlerden ötürü alıntı kelimelerde az veya çok ses değişiklikleri veya ses olaylar1 meydana gelir."5

emr > emir, hukm > hükm hüküm, gūşe > köşe, menāre > minare, çünki > çünkü, derd $>$ dert, kitāb > kitap, zảif $>$ zayıf, dĩvār $>$ duvar gibi sayısını çoğaltılabilecek bu örnekler Arapça ve Farsçadan alıntılanan kelime veya yapıların bazı fonetik değişikliklere uğradıklarını göstermektedir.

$\mathrm{Bu}$ örneklerden hareketle temel olarak Türkçeleştirilen yapılarda görülen fonetik hadiseler yaygın olarak ses türemesi, ünlü yuvarlaklaşması, ünlü düzleşmesi, ünlü incelmesi, ünlü kalınlaşması, sedasızlaşma vb. olarak sıralanabilir. Günümüz Türkçesinde söz konusu yapıların Türkçeleşmiş şekillerinin veya kaynak dildeki şekillerinin kullanılmaya devam ettiği pek çok örnekle sabittir. Bugün de bu kelimelerin Türkçeleşmiş yaygın şekilleri hem yazı dilinde hem de konuşma dilinde yadırganmadan ve doğru kabul edilerek kullanılmaktadır. Ancak özellikle

4 Şirin User, Başlangıçtan Günümüze Türk Yazı Sistemleri, 96.

5 Sadettin Özçelik, “Türkçedeki Farsça Kelimelerde Görülen Ses Olayları”, Türk Dili Dergisi (2002), 1033. 
söz konusu dillerden Türkçeye geçmiş gramer şekillerinin Türkçeleştirilmesinde dilin doğal gelişimine aykırı olarak kaynak dillerdeki şekillerin korunmasında daha tutucu bir tavır sergilenmektedir. Bu durum özellikle çeviri yazı yoluyla yapılan aktarmalarda dikkat çekmekte ve bize göre bir sorun teşkil etmektedir. Aslında tarihî metinlerdeki pek çok kullanım örneği söz konusu tutuculuğun daha çok günümüz çalışmalarında var olduğunu göstermektedir. Pek çok tarihî metinde Arapça ve Farsça başta olmak üzere diğer dillerden yapılan alıntıların kaynak dilden farklılık gösteren telaffuzları çeşitli imla yollarıyla yazıda da gösterilmeye çalışılmıştır. Ancak bu durum çoğunlukla müellif veya müstensihlerin bilgisizliğine veya ihmaline hamledilerek düzeltme yoluna gidilmektedir. Fakat durumu sadece müellif veya müstensihlerin bilgisizliği veya ihmali olarak izah etmenin doğru olmadığg kanaatindeyiz. Aksine bu yazımların Türkçeye ait fonetik ve morfolojik değişimlerin imla yoluyla gösterilmesi ve birer ağız özelliğgi olarak değerlendirilmesi gerektiğini düşünmekteyiz. Zira ḥākim-ü ervāḥ-l

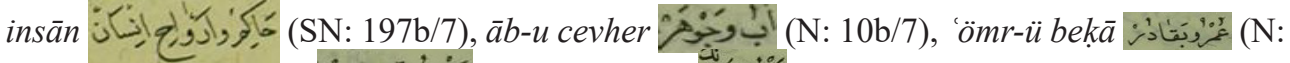
239b/7), ma şūk l âşılk izafet kesresinin ötreli vav ve atıf tamlamalarındaki bağlayıcı unsurun esreli $y$ ile yazılması müstensihlerin bu imlayı şuurlu bir şekilde kullandıkları ve ağız özelliklerini yansıtmak istediklerini düşündürmektedir.

Dilin canlı bir varlık olduğu özelliğinden hareketle Türk dilinin de tarih boyunca fonetik ve morfolojik değişimlere uğradığı bilinen bir gerçektir. Bu değişimler dil çalışmalarının merkezinde önemli bir yer tutmakta ve araştırmacıların çalışma alanlarının başında gelmektedir. "Elimizde herhangi bir ses kaydı olmadığı için Türkçenin tarihî dönemleriyle ilgili değerlendirmeler daima yazılı kaynaklardan hareketle yapılmakta, metinlerdeki imla özelliklerinden hareketle o dönemlerin fonetik özellikleriyle ilgili genel kurallar ortaya konmaktadır." ${ }^{6}$ Özellikle bir ses kaydı özelliği taşıyan harekeler bu tespitlere imkân tanımaktadır. Dolayısıyla metin aktarımlarında harekelerle ilgili nüansların dikkatten kaçırılması veya yanlış yazıldığı düşünülen harekelerin düzeltilme yoluna gidilmesi Türk dilinin ağız özelliklerinin ve fonetik gelişmelerinin tam anlamıyla ortaya konulamamasına yol açmakta ve âdeta aktarımı yapılan metinden farklı bir metin/nüsha oluşturulmaktadır.

Türk Dil Kurumu Güncel Türkçe Sözlük’te çeviri yazı için yapılan “Bir yazıyı bütün ses inceliklerini belirterek başka bir alfabeye çevirme yolu, yazı çevirimi, transkripsiyon. "’ şeklindeki tanımdan da anlaşılacağı üzere çeviri yazı bir metni bir alfabeden başka bir alfabeye aktarma işidir. Dolayısıyla metin neşri yapan araştırmacıların müellif ve müstensihlerin kullanımlarına müdahaleleri söz konusu metinlerin Türk dili çalışmalarına kaynaklık etmesi bakımından bir eksiklik meydana getirmektedir.

6 Ali İhsan Yapıcı, "Eski Anadolu Türkçesi ve Osmanlı Türkçesi Metinlerinde İmla Kaynaklı Bir Sorun: Ünsüz Uyumu”, Uluslararası Sosyal Araştırmalar Dergisi (2020), 252.

7 Türk Dil Kurumu. Güncel Türkçe Sözlük. (Ankara: TDK Yayınları, 2009), 419. 
Türkoloji çalışmalarında genel olarak benimsenen çeviri yazı usulü İsmail Ünver, Adnan İnce ve Osman Horata gibi bilim insanlarının ortaya koymuş oldukları görüşler ${ }^{8}$ etrafında şekillenmektedir. Bu görüşler çeviri yazı usulleriyle ilgili pek çok sorunu çözmekle ve büyük oranda bir yazım birliği sağlamakla beraber özellikle Türk dilinin fonetik ve morfolojik değişimlerini tespit etmede ve tarihî metinlerdeki ağız özelliklerinin tam olarak ortaya konması hususunda yetersiz kalmaktadır.

Tarafımızca tespit edilen sorun, özellikle Farsça izafet ve atıf tamlamalarında meydana gelen fonetik hadiselerin çeviri yazıya aktarımındaki eksikliklerle ilgilidir. Metin neşri yapan araştırmacıların pek çoğu genellikle yazma nüshalarda yer alan Farsça izafet tamlamalarının ötreli şekillerini, atıf tamlamalarının esreli şekillerini çeviri yazılı metinlere yansıtmamaktadırlar. Tarihî metinlerdeki bu kullanımlar ya görmezden gelinmekte ya da yanlış kabul edilerek kaynak dildeki şekiller tercih edilmektedir.

Bu yazıdan maksat yukarıda bahsedilen kullanımların birer yanlış olmadığı, bu ses değişmelerinin doğal fonetik birer hadise olduğu ve bu kullanımların çeviri yazıda nasıl değerlendirilmesi gerektiğini araştırmacıların dikkatine sunmaktır.

Bu çalışmada 14 farklı yazma eserden tespit edilen örneklere yer verilmiştir. Ancak taranan eserlerde yer alan örneklerin hepsi bu çalışmaya dâhil edilmemiştir. Genellikle aynı eserde yer alan ve tekrar eden örneklerden birine yer verilmiştir. Esasen rastlanılan örneklerin tamamına yer verilip kullanım sıklığı gösterilmek istense de makale boyutunu aşacağından birbirinden farklı örneklere yer vererek Farsça izafet ve atıf tamlamalarındaki dudak uyumunun yaygınlığının ortaya konması amaçlanmıştır. Bununla birlikte aynı örneğin farklı eserlerde tespiti durumunda, kullanım sıklığının gösterilmesi amacıyla çalışmada bu örneklere yer verilmeye özen gösterilmiştir. Yukarıda ifade edildiği üzere dile getirdiğimiz husus bazı araştırmacıların dikkatini çekmiş ve bu durumdan kısaca bahsetmişlerdir. ${ }^{9}$ Araştırma esnasında rastlanılan bu çalışmalara ait yazma eserlerin tamamına ulaşma imkânı olmadığından yazma nüshadan tanıklanmayan örneklere yer verilmemiştir. Dolayısıyla bahsedilen durumun burada yer verilen örneklerden daha fazla örnekte ve eserde görülebileceğini söylemek yanlış olmayacaktır. Konuyla ilgili örneklerin sayısının ve çeşitliliğinin taranacak eser sayısına bağlı olarak artacağı muhakkaktır. Bu yazıda Farsça izafet ve atıf tamlamalarında meydana gelen dudak uyumu incelenmiş ve bu uyuma bağlı olarak oluşan imlanın çeviri yazıda nasıl gösterilmesi gerektiğiyle ilgili önerilere yer verilmiştir.

8 Konu ile ilgili detaylı bilgi için bkz. Adnan İnce, "Tenkitli Metin Kurmada Karşılaşılan Güçlükler ve Çözüm Önerileri” (I. Eski Türk Edebiyatı Kollogyum, İLESAM, Ankara, Ocak 17-18, 1992); İsmail Ünver, "Çeviriyazıda Yazım Birliği Üzerine Öneriler", Turkish Studies 3(6) (2008); Osman Horata, "Klâsik Edebiyatımıza Ait Metinlerin Neşrinde Karşılaşılan İmlâ ile İlgili Bazı Problemler” (I. Eski Türk Eski Türk Edebiyatı Kollogyumu, İLESAM, Ankara, Ocak 17-18, 1992).

9 Daha ziyade lisansüstü çalışmaların dil incelemesi bölümlerinde değinilen bu konuyla ilgili bazı çalışmalar şunlardır: Akın, 2011; Coşkun, 2019; Divli, 2019; Ersoylu, 1996; Kalkan, 2012; Kaplan, 2019; Keskin, 2020; Özcan, 2007; Taş, 2016; Tuğluk, 2018; Uluscu, 2013; Yastı, 2010; Yeldan, 2019. 


\section{Farsça İzafet Tamlamalarındaki İzafet Kesresinin vav, ötreli vav veya Sadece ötre ile Gösterilmesi}

Aşağıdaki örnekler incelendiğinde Farsça izafet tamlamalarındaki yuvarlaklaşma eğiliminin Türk dilinin dudak uyumuyla ilgili fonetik bir hadise olduğu anlaşılmaktadır. Yuvarlaklaşma görülen örneklerin çoğunda izafet tamlamasının birinci unsurunda ya yuvarlak bir ünlü veya yuvarlaştırıcı etkisi olan bir dudak ünsüzünün varlığı dikkat çekmektedir. Dolayısıyla yazma eserlerde karşılaştığımız izafet kesresinin vav, ötreli vav veya sadece ötre ile gösterilmesi dudak uyumuna bağlı olarak ünlü yuvarlaklaşması hadisesidir. Konuyla ilgili tespit edilen örnekler şu şekildedir:

Her gönül kim anda ḥubb-u dünya dolmış ola. (EA: 44b/4)

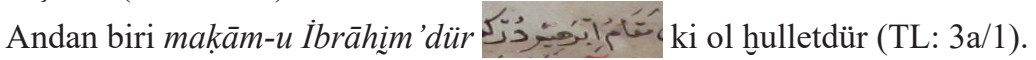

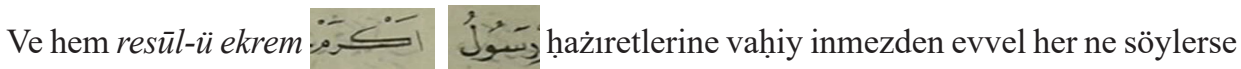
düşde görüp söylerdi (TM: 2b/2-4).

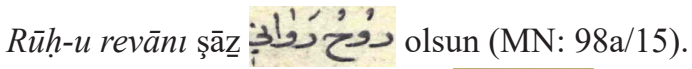

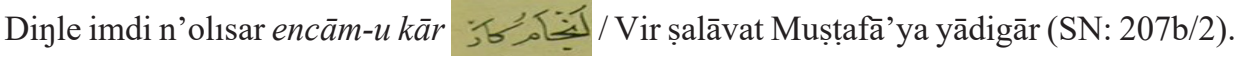

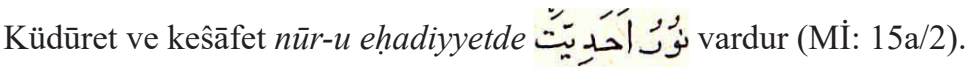

İmdi ol degüldür illā rūḥ-u pāk-ı Muhammedi

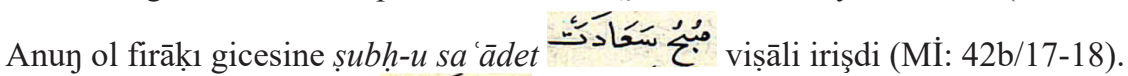

Ol ḳara țopragì $1 \bar{a} b-u$ tahūr

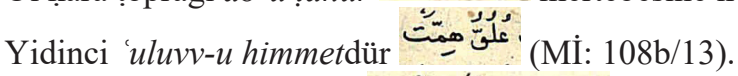

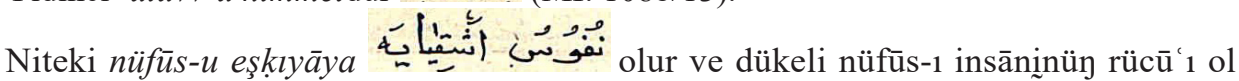
Hażret'edür (MI: 160b/1-2).

İy çalabım āhiretde yüzümi senin nūrıpıla ak etgil yevm-ü kıyāmet evliyāların yüzleri aḳ olıcaḳ... (RSİ: 31b/4-5).

Didi kim ben sizi Haḳ'dan dileyem/Rūz-u mahşerde

Her kitābı medḥe lāyıḳ șanma șaḳın sen hemān / Gel kitābu'llāhı medḥ it hükkm-ü Bārị 'dür >حِ

Terk ider dār u diyārın țālib-ü irfān kitāb (TS: 16b/5-6).

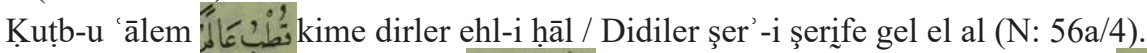

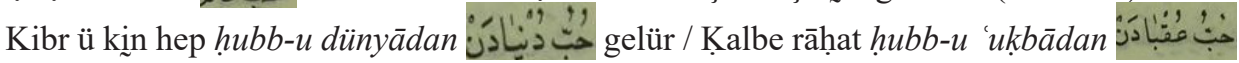
gelür (N: 51b/6).

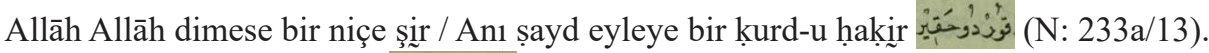

Kes ümidim ‘ömr-ü fānidden 


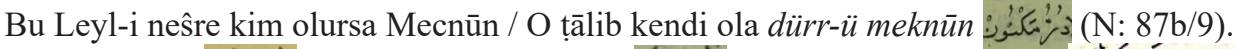
āb-u 'umman

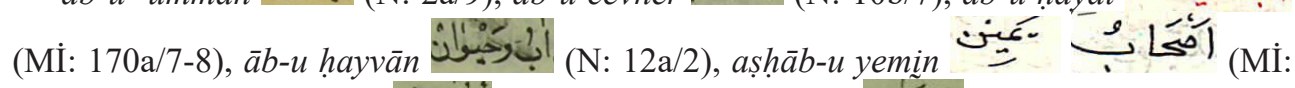

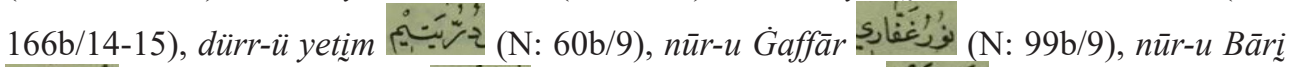

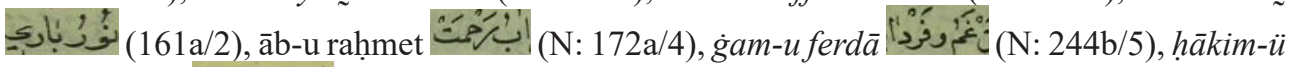

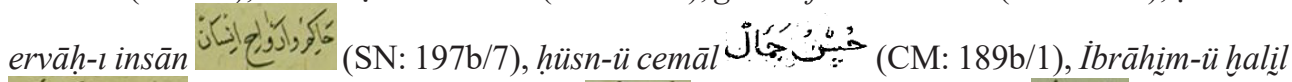

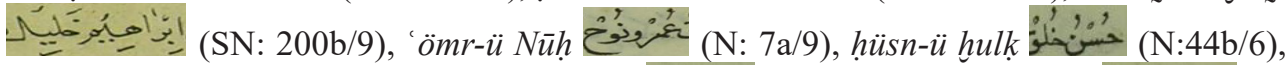

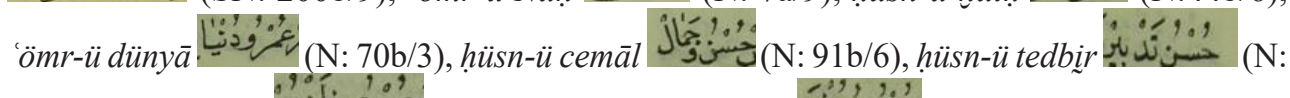

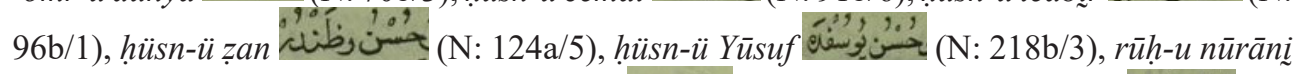

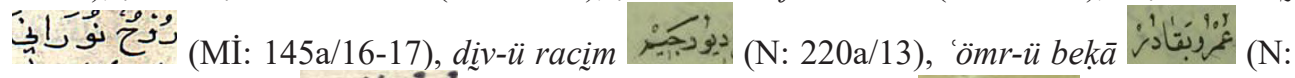

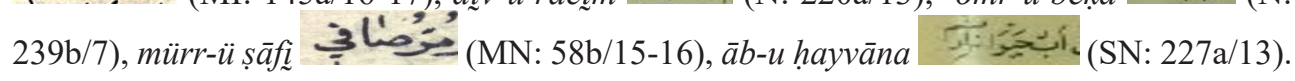

\section{Farsça Atıf Tamlamalarında Bağlayıcı Unsurun y, esreli y veya Sadece esre ile Gösterilmesi}

Farsça atıf tamlamalarındaki atıf vavının düzleştiği örneklerin geneline bakıldığında izafet kesresinin yuvarlaklaşması bahsinde belirtildiği gibi ses değişmesine etki eden bir unsurun varlığı dikkat çekmektedir. Atıf tamlamalarındaki bağlayıcı unsurun düzleşmesine bir düz ünlü veya yanında düz ünlü isteyen /1/,/s/, /ş/ ve /ç/ gibi ünsüzler sebep olmaktadır. Başka bir deyişle atıf tamlamalarında görülen ünlü düzleşmesinin sebebini de izafet tamlamalarındaki izafet kesresinin yuvarlaklaşması hadisesinde olduğu gibi ünlü uyumu ve ünlü-ünsüz uyumu olarak açıklamak mümkündür. Atıf tamlamalarındaki bağlayıcı unsurun düzleşmesi hadisesiyle ilgili tespit edilen örnekler şu şekildedir:

İllā içi țolıyıdı kibr $i$ kin

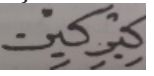

/ Muṣțafā'ya düşmānıdı ol la in (KD: 19b/8).

'Avrat eydür zinhār uyma mahremim / Ey benim dil-dār l yārim ولخديفابن hem-demüm (KD: 21a/13).

Ins $i$ cinnile 208b/19).

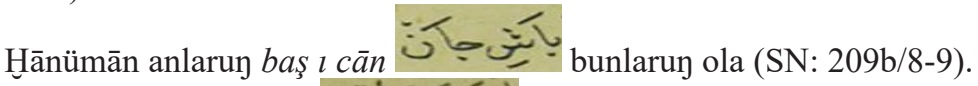

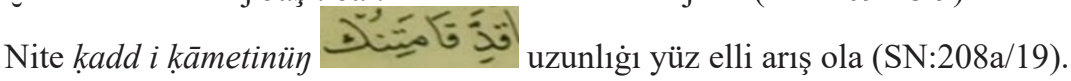

Pes Āंdem peyġamber 'aleyhi’s-selām Muḥammed 'aleyhi's-selāma selām virdi şöyle sevindi şāz $\imath$ h hurrem

Eger degilse bend $i$ zindān

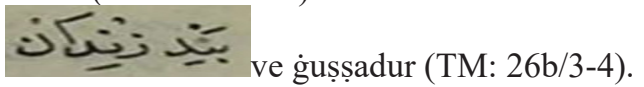




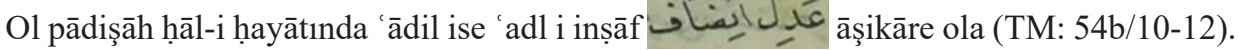
Gökler ve 'arş ve kürsi ve levh ve ḳalem ve burūc ve eflāk ve kevākib i seyyārāt

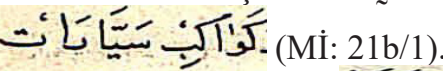

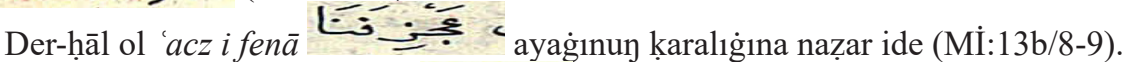

Şöyle șandılar ki tesbịh i ŝena $\bar{a}$ (Mí: 25b/1).

Her nesne ki gajayibden aya irişe kabż l basțdan ve renc i rāḥatdan ve șlḥhat l marażdan ن

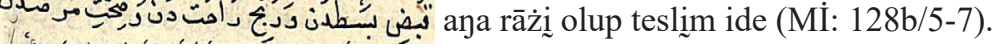

Eger ṣon demde ĩmānum çırāgin itmesen bāṭl / Șafā vü żevk $i$ şevkile virem ben cānı el-ḥāṣ̂l (Mİ: 191a/18-19).

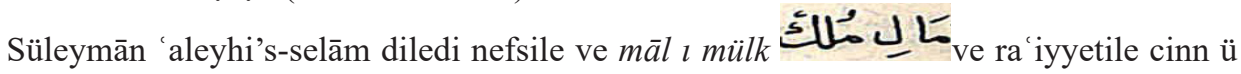
insden ve vuhūş u țuyūrdan ve dahıı memleket āletleriyle ve salțanat esbābıyla Haḳ’uy hiżmetin ve 'ubūdiyyetin yirine getüre (Mİ: 202a/2-5).

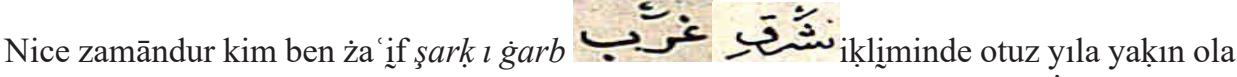
ki țavāf iderem hịç bir ḳạ̣̄i görmedüm ki bu āfetlerden beri olup halāṣ bula (Mİ: 237a/3-5).

Ya ni dimek olur bir nice kişiler vardur ki bey ' $i$ şira șūretinde egerçi ẓāhir ola velākin gönüllerin Hak zikrinden ḳomayalar (Mİ: 247a/10-12).

Kendüye ve ehl $i$ 'ayāline

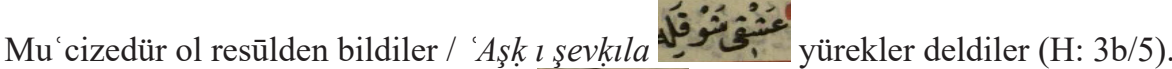

Katı katı ağladı ol demde ol / $\bar{A} h$ l zâr

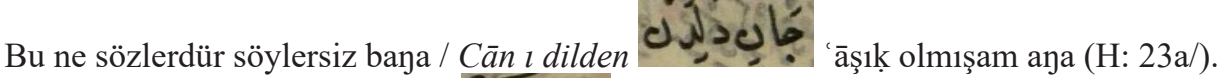

Anıpla ḳılmağ1l sen ahd i piymān

Eger 'ābid olursa cinn i insān (H: 41/b).

İns ü cinn ü vahş c tayr hem felek (DM: 7b/3).

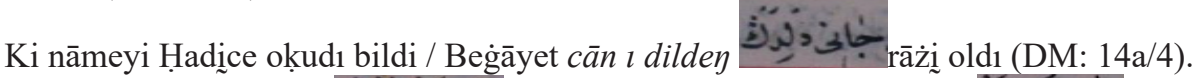

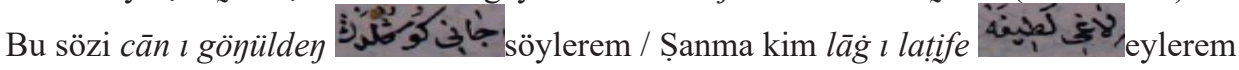
(DM: 40b/8).

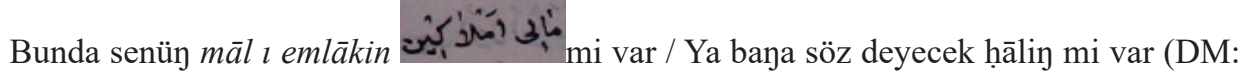
$51 \mathrm{~b} / 7)$.

Gehi üç günde bir yer etmek $i$ aş 
Oḳu Kur ânı emr i nehyi

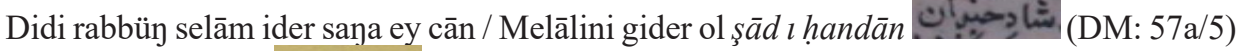
Karaluy taht $\imath$ tācnı durur ey han (N: 2a/6).

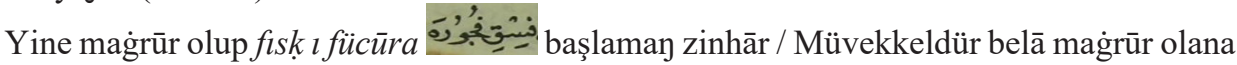
iy Kִırım halḳı (N: 9a/4).

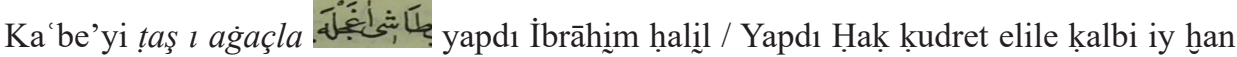
ḳulları (N: 17a/4).

Ki zi্rā māl l 'asker azdur iy Tūnūs halḳı (N: 18b10).

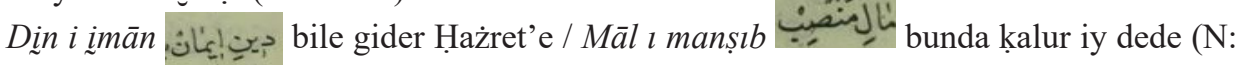
26b/14).

Bu żulüm Fir 'avn ı Hāmān işidür (N: 27a/8).

Kim ki Ḳur'ān ı hadiŝse

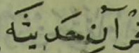

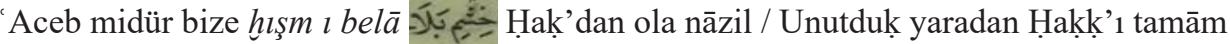
iy ḩalḳ-1 İslāmbol (N: 28b/2).

Senün ol sevdigin māl l haziney halḳ-1 İslāmbol (N: 29a/13).

Çürütdük nāzenin ‘ ömri hevāda fisk $\iota$ 'ișyānda / Hużūr-1 Haḳk’a biz varmaz mıyuz iy Ādemog̉lanı (N: 33b/15).

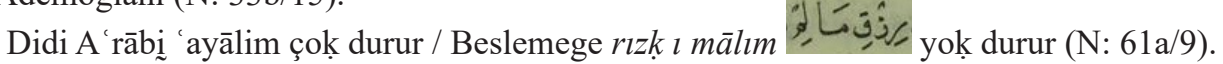

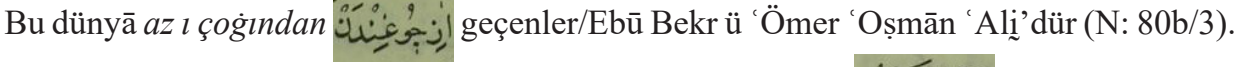

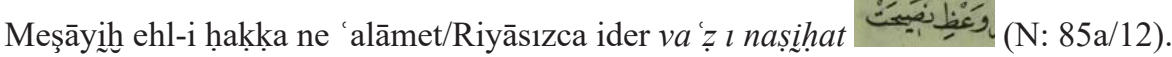

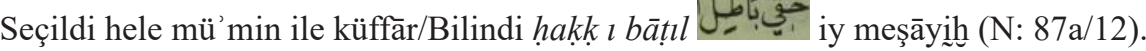

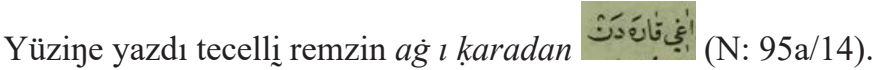

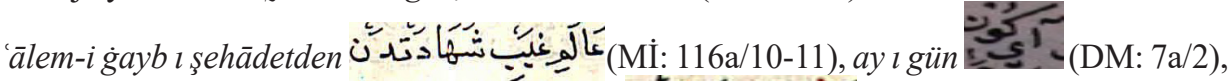

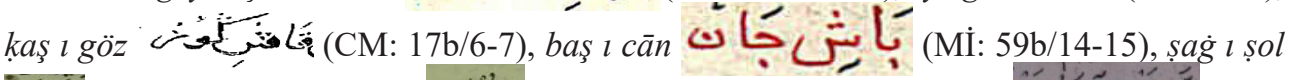

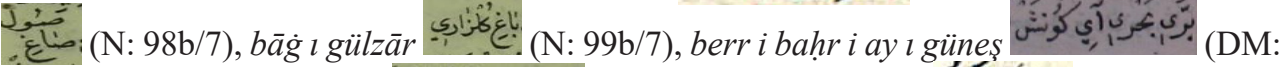

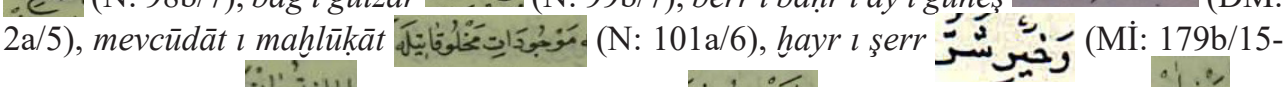

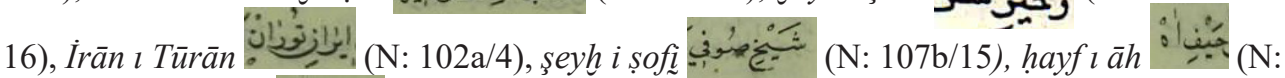

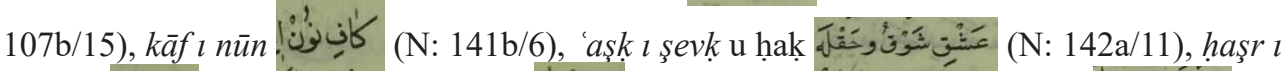

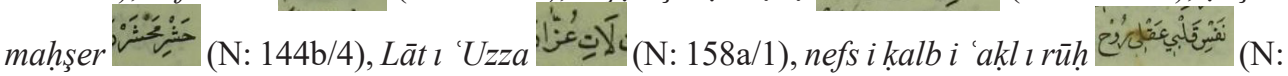


167b/15), 'arş ı kürsi S1 (Mi: 6a/11-12), eri 'avrat

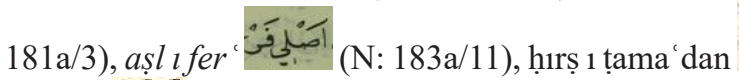

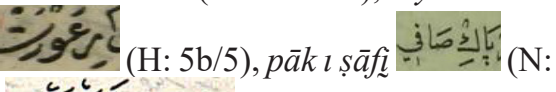
نَّ人 181a/3), asl f ferisi: 231b/18-19), kavl

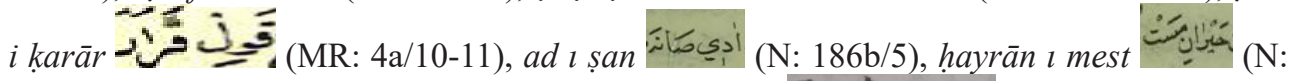

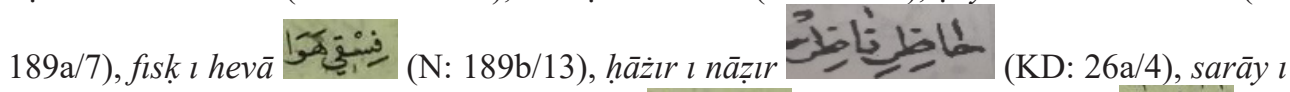

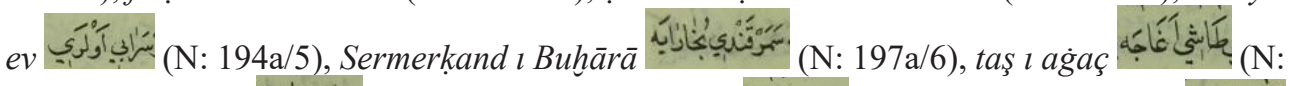

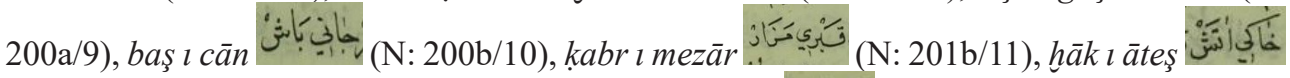

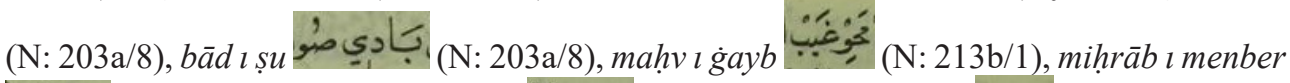

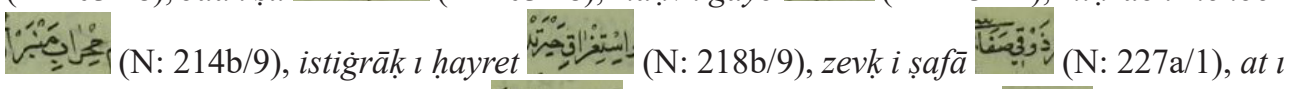

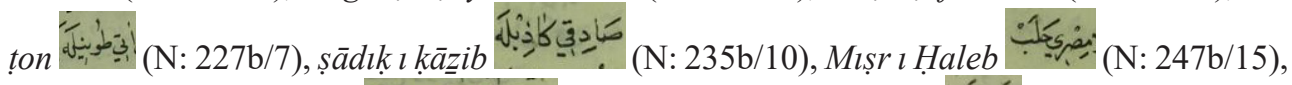

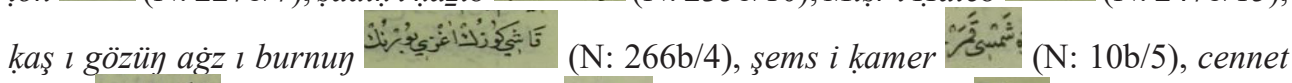

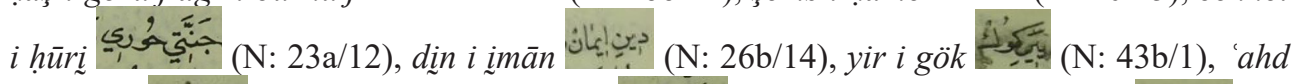

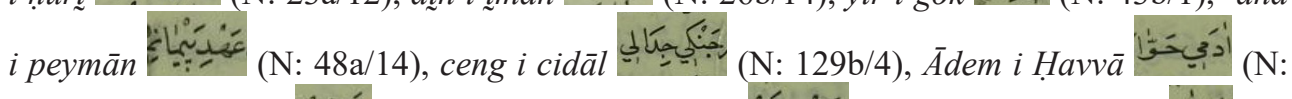
135a/1), nahvv i șarf

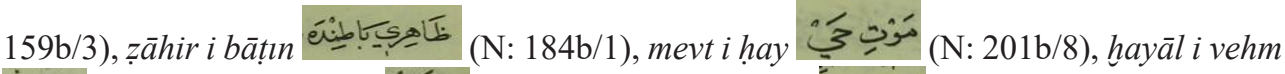

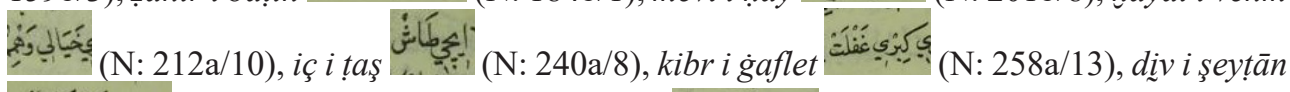

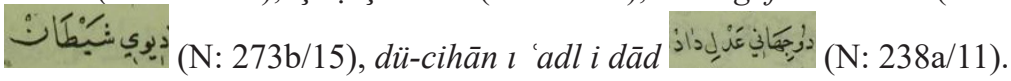

\section{Farsça İzafet ve Atıf Tamlamalarında Dudak Uyumuna Aykırı Olarak Meydana Gelen Ses Olayları}

Yapılan incelemeler esnasında hem izafet tamlamalarında hem de atıf tamlamalarında dudak uyumuna aykırılık gösteren bazı örneklere de rastlanmıştır. Ancak bu örneklerin sayısı dudak uyumuna giren örneklere nazaran çok daha azdır. Bize göre uyuma aykırılık gösteren örnekler dönemin yaygın imlasının etkisi veya müstensihlerin ağız özelliklerinin yansımasıdır. Taranan eserlerin yüzyıllarına bakıldığında örneklerin sıklığı XVII ve XVIII. yüzyıllara ait metinlerde yoğunlaşmaktadır. Bu yüzyıllarda dudak uyumunun yaygınlaştığı göz önüne alındığında Farsça izafet ve atıf tamlamalarında görülen ünlü yuvarlaklaşması ve ünlü düzleşmesi hadisesinin bazı ağızlarda genel bir imla özelliği olduğu dolayısıyla aykırılık gösteren örneklerin de genel imlanın etkisiyle ve benzeşme yoluyla meydana geldiği düşünülebilir. Dudak uyumuna aykırılık gösteren örnekler şu şekildedir: 


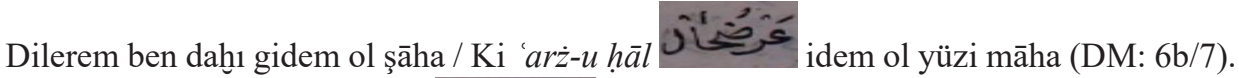
Gelecek hem ana Cibril-ü emin

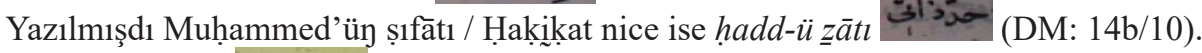

Hamd-ü bì-had kāyinātı üstüvār (SN: 197b/1).

Hamd-ü bi-nihāyet vücūdı anuy 'ațāsı neticcesidür (Mİ: 1b/2-3).

Kardaşı̇dan isteme ḳarż-u hasen $112 \mathrm{a} / 12)$.

Diledi kim ey ṣāni '-ü şems (KD: 26a/3).

Ṣalavāt-u bi-had ervāḥ-1 muḳaddesün üzerine olsun (Mİ: 1b/12-14).

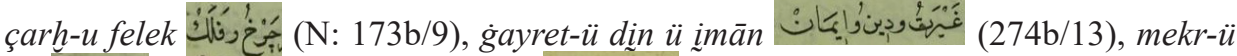
şeytān

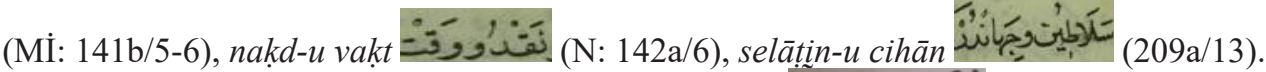

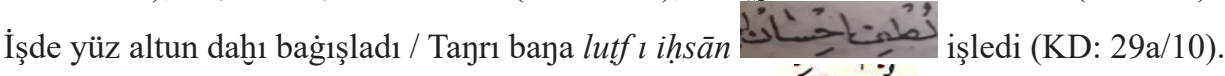

İkinci vech budur ki zaāt-1 ehadiyyet mevṣûfdur lutf $\imath$ kahr

Mebde' bābında fițat-1 ervāḥun bidāyeti ve mülk i melekūtuy olisar (Mİ: 6a/10-11).

Șubh l şām

Biz bu yoḳsıllıg̉a rāżı olmışuz / Bu deme şükr i kanā at

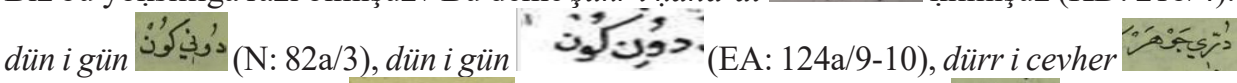

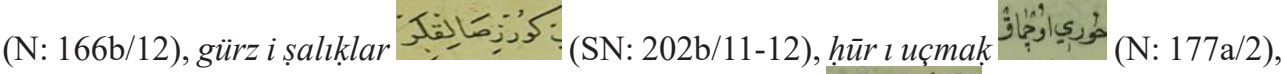

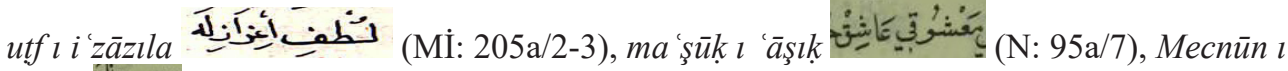

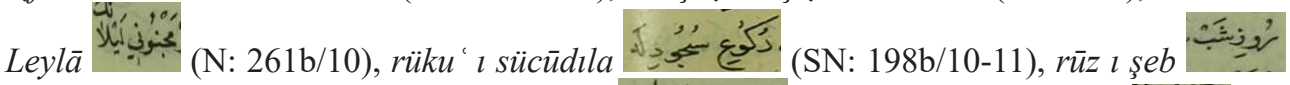

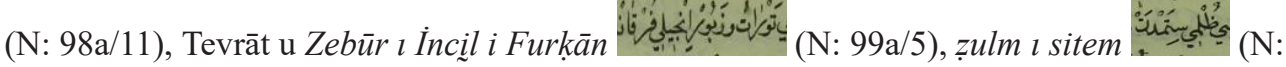
$271 \mathrm{~b} / 6)$. 


\section{Sonuç ve Öneriler}

Birbirleriyle ilişki kuran toplumların birbirlerinin dillerinden kelime alışverişleri yapmaları doğaldır. Bazen bu etkileşim kelime alışverişlerinin ötesinde dillerin gramer kuralları bakımından birbirlerini etkilemesi şeklinde de görülebilir. ${ }^{10}$ Yukarıda görüldüğü gibi farklı tarihlerde ve farklı müellif veya müstensihler tarafından yazılmış pek çok eserde görülen izafet kesresinin vav, ötreli vav veya sadece ötre ile yazımını ve atıf tamlamalarının bağlayıcı unsurunun $y$, esreli y veya sadece esre ile yazımını müellif veya müstensihlere ait bilgisizlikler ve ihmallerle izah etmenin mümkün olmadığı görülmektedir. Aksine yazma eserlerden tespit edilen bu imla özelliklerinin bilinçli kullanıldığını düşünmekteyiz. Bu noktadan hareketle:

1. Farsça izafet ve atıf tamlamalarında meydana gelen ses değişmelerinin Türk dilinin kendine mahsus kuralları içerisinde gerçekleşen doğal fonetik hadiseler olarak kabul edilmesi ve çeviri yazı yoluyla yapılan aktarımlarda harekeye uyulması dil çalışmaları açısından daha uygun olacaktır.

2. Farsça izafet tamlamalarında izafet kesresi vav, ötreli vav veya sadece ötre ile imla edildiyse çeviri yazıda -u veya -ü (șubh-u sa āadet, rūh-u pāk, āb-u hayāt, dürr-ü yetìn vb.) şeklinde yazılması gerektiğini düşünmekteyiz.

3. Farsça atıf tamlamalarında bağlayıcı unsur $y$, esreli $y$ veya sadece esre ile imla edildiyse çeviri yazıda $l$ veya $i$ (cān $l$ gönül, ehl $i$ 'iyăl, hayr $l$ şer, șubh $l$ şām vb.) şeklinde yazılması gerektiği kanaatindeyiz.

$\mathrm{Bu}$ tercihler, Türk dilinin tarihî metinlerinin hem ses hem de ağız özelliklerinin doğru yansıtılmasına ve özellikle ses bilgisi çalışmalarında tarihî metinlerin daha işlevsel kılınmasına imkân tanıyacaktır.

Hakem Değerlendirmesi: Dış bağımsız.

Çıkar Çatışması: Yazar çıkar çatışması bildirmemiştir.

Finansal Destek: Yazar bu çalışma için finansal destek almadığını beyan etmiştir.

Peer-review: Externally peer-reviewed.

Conflict of Interest: The author has no conflict of interest to declare.

Grant Support: The author declared that this study has received no financial support.

\section{Kaynaklar/References}

Akar, Ali. "Eski Oğuz Lehçesinde Alfabe Kaynaklı Fonolojik Bir Sorun: Ünsüzlerin Yazımı.” Türkiyat Mecmuası 31, 1 (2021).

Akın, Lemi. "Cevâhirü'l-Ma'ân̂̂ (Paris Nüshasl) Metin ve Söz Dizimi İncelemesi.” Doktora Tezi, İstanbul Üniversitesi, 2011.

10 Fatma Özkan ve Bağdagül Musa, "Yabancı Dillerin Türkçenin Söz Dizimi Üzerindeki Etkisi”, Bilig 30 (2004), 96. 
Çoşkun, Recep. "Dâsitân-ı Mustafâ Giriş-İnceleme-Metin-Dizinler-Tıpkıbasım.” Yüksek Lisans Tezi, Necmettin Erbakan Üniversitesi, 2019.

Divli, Feyzullah. "Hikâyât (Giriş, Dil İncelemesi, Transkripsiyonlu Metin, Gramatikal Dizin-Sözlük, Tipkıbasım)." Yüksek Lisans Tezi, Kocaeli Üniversitesi, 2019.

Ercilasun, Ahmet Bican. Başlangıçtan Yirminci Yüzyıla Türk Dili Tarihi. Ankara: Akçağ Yayınları, 2008.

Ergin, Muharrem. Türk Dil Bilgisi. İstanbul: Bayrak Yayınları, 2006.

Ergin, Muharrem. Osmanlıca Dersleri. İstanbul: Boğaziçi Yayınları, 1997.

Ersoylu, Halil. Kız Destanı (Hazâ Hikâyet-i Kız Ma'a Cühû). Ankara: TDK Yayınları, 1996.

Horata, Osman. "Klâsik Edebiyatımıza Ait Metinlerin Neşrinde Karşılaşılan İmlâ ile İlgili Bazı Problemler" I. Eski Türk Eski Türk Edebiyatı Kollogyumu, ILLESAM, Ankara, 17-18 Ocak 1992.

İnce, Adnan. "Tenkitli Metin Kurmada Karşılaşılan Güçlükler ve Çözüm Önerileri” I. Eski Türk Edebiyatı Kollogyumu, İLESAM, Ankara, 17-18 Ocak 1992.

Kalkan, Sultan. “Abdu'r-rahmâni'd-Darîr Tezkiretü s-Salât (Giriş-İnceleme-Metin-Sözlük). ”Yüksek Lisans Tezi, Süleyman Demirel Üniversitesi, 2012.

Kaplan, Savaş. "Firdevsîi-i Rûmî Süleymân-nâme (29 ve 30. Ciltler) (Giriş-İnceleme -Metin-Dizin-Tıpkıbasım)." Doktora Tezi, Marmara Üniversitesi, 2019.

Keskin, Gülcan. “Tuhfetü 'l-Mülûk (Giriş-İnceleme-Metin-Dizin-Tipkıbasım). ”Yüksek Lisans Tezi, Kastamonu Üniversitesi, 2020.

Korkmaz, Zeynep. “Eski Osmanlı Kaynaklarının Yayınında Transkripsiyonla İlgili Değerlendirmeler.” Türkoloj Dergisi 8, 1 (1979).

Özcan, Hatice. "Kaysûnîzâde Nidâi Muhammed Çelebi El-Ankaravî̀nin Menâfí u'n-Nâs Adlı Eseri (Metin-Dil Özellikleri-Dizin). ”Yüksek Lisans Tezi, Selçuk Üniversitesi, 2007.

Özçelik, Sadettin. “Türkçedeki Farsça Kelimelerde Görülen Ses Olayları.” Türk Dili Dergisi (2002).

Özkan Fatma, Musa Bağdagül. "Yabancı Dillerin Türkçenin Söz Dizimi Üzerindeki Etkisi.” Bilig 30 (2004).

Şirin User, Hatice. Başlangıçtan Günümüze Türk Yazı Sistemleri. Ankara: Akçağ Yayınları, 2006.

Taş, İsmail. “Eski Anadolu Türkçesi Dönemi Eserlerinden Tefsirü 'l-Lübâb Tercümesi Üzerine Dil İncelemesi (Giriş-Inceleme-Metin-Sözlük).” Doktora Tezi, İstanbul Üniversitesi, 2016.

Timurtaş, Faruk Kadri. Osmanlı Türkçesine Giriş Eski Yazı-Gramer-Aruz-Metinler. İstanbul: Alfa Yayım Dağıtım, 1999.

Tuğluk, Mehmet Emin. “17. Yüzyll'a Ait Harekeli Bir Eser: Kâdirî Muhyiddîn'in Manzum Nasîhat-nâmesi (Inceleme-Metin-Sözlük-Özel İsimler Dizini-Tipkıbasım). ” Doktora Tezi, Adıyaman Üniversitesi, 2018.

Türk Dil Kurumu. Güncel Türkçe Sözlük. Ankara: TDK Yayınları, 2009.

Uluscu, Gizem. “Eski Anadolu Türkçesiyle Yazılmış Miraçname (Metin-Gramer-Dizin). ”Yüksek Lisans Tezi, İstanbul Üniversitesi, 2013.

Ünver, İsmail. “Çeviriyazıda Yazım Birliği Üzerine Öneriler.” Turkish Studies 3, 6 (2008).

Yapıcı, Ali İhsan. "Eski Anadolu Türkçesi ve Osmanlı Türkçesi Metinlerinde İmla Kaynakı1 Bir Sorun: Ünsüz Uyumu." Uluslararası Sosyal Araştırmalar Dergisi 13, 73 (2020).

Yast1, Mehmet. "Esrârü'l- 'Ârifin (İmla-Metin-Dizin). ” Doktora Tezi, Selçuk Üniversitesi, 2010.

Yeldan, Fatma. "Risâle-i Su'âl-i İblîs, (Giriş-Ses Bilgisi-Metin-Dizinler-Tıpkıbasım).” Yüksek Lisans Tezi, Necmettin Erbakan Üniversitesi, 2019. 


\section{Kisaltmalar}

CM : Cevâhirü'l-Me'ânî, Paris Bibliotheque Nationale, Supp. 499.

DM : Dâsitân-1 Mustafâ, Koyunoğlu Şehir Müzesi ve Kütüphanesi Yazma Eserler Kataloğu, 13775.

EA : Esrârü’l-Ârifîn, Süleymaniye Kütüphanesi, Fatih Kitaplığı, 2557-1.

H : Hikâyât, Milli Kütüphane 06 Hk 1637/5.

KD : Kız Destanı, Topkapı Sarayı Müzesi Kütüphanesi Y.520.

MI : Mirsâdü'l- '̇bâd, Süleymaniye Kütüphanesi, Hacı Mahmud Efendi, 2235.

MN : Menâfi'u’n-Nâs, Milli Kütüphane, 06 Mil Yz A 576.

MR : Miraç-nâme, Süleymaniye Kütüphanesi, 297.9.

N : Nasîhat-nâme, Topkapı Sarayı Müzesi Kütüphanesi, Y.2636.

RSİ : Risâle-i Su'âl-i İblis, Konya Yazma Eserler Kütüphanesi, 42 Kon 5407/1.

SN : Firdevsî-i Rûmî, Süleymân-nâme, C. 10, Topkapı Sarayı Müzesi Kütüphanesi, H.1525.

TL : Tefsirü'l-Lübâb, Bursa Yazma Eserler Kütüphanesi, 435.

TS : Tezkiretü’s-Salât, Milli Kütüphane, 06 Mil Yz A 8890.

TM : Terceme-i Tuhfetü'l-Mülūk, Çorum Hasan Paşa İl Halk Kütüphanesi, 19 Hk 3099. 